\title{
Powrót do przeszłości? O przemianach prawnych mechanizmów regulacji pamięci zbiorowej w Hiszpanii z perspektywy Europy Środkowej
}

\section{Wstęp}

W 1993 r., w przeddzień wyborczego zwycięstwa Sojuszu Lewicy Demokratycznej (wówczas jeszcze koalicji lewicowych ugrupowań, a nie jednolitej partii), „Gazeta Wyborcza” opublikowała wywiad Redaktora Naczelnego Adama Michnika z Bronisławem Geremkiem. Poza obawami co do dalszego kierunku polskich przemian, pojawił się w nim także wątek rozliczeń z czasami PRL i niedawną niedemokratyczną przeszłością. Cały wywiad był z kolei próbą rozrachunków z jego własnym obozem politycznym, który nie tylko pozwolił na powrót do władzy postkomunistów zaledwie cztery lata po pierwszych częściowo wolnych wyborach z czerwca 1989 r., ale także - wskutek wewnętrznych konfliktów - ostatecznie doprowadził (dwa dni później) do ukonstytuowania się tzw. sejmu bez prawicy². Na pytanie A. Michnika o kierunek, w jakim przemiany powinny zmierzać (wobec zwycięstwa lewicy postkomunistycznej i postsolidarnościowej), B. Geremek stwierdził m.in., że:

Chęć zemsty, jaką przejawiają nawet osoby umiarkowane w poglądach, jest uzasadniona bilansem PRL-u, ale uczucie to nie może zastępować kardynalnej zasady równości ludzi wobec prawa. Nie sądzę, żeby dekomunizacja jako naruszenie zasady państwa prawa mogła mieć jakikolwiek pozytywny wpływ na polską rzeczywistość 3 .

\footnotetext{
Numer ORCID: 000-0003-2669-7822. Adres e-mail: fcyunczyk@swps.edu.pl

SLD uzyskał w tych wyborach 2815169 głosów, co przełożyło się na 171 mandatów, drugie było Polskie Stronnictwo Ludowe (2 124367 głosów i 132 mandaty), trzecie i czwarte miejsca zajęły zaliczane do „lewicy solidarnościowej” Unia Demokratyczna i Unia Pracy (odpowiednio 1460957 głosów - 74 mandaty; 1005004 głosy - 41 mandatów). Ugrupowania zaliczane do nurtu konserwatywno-narodowego - Konfederacja Polski Niepodległej (KPN) i skupiony wokół prezydenta Lecha Wałęsy Bezpartyjny Blok Wspierania Reform (BBWR) - otrzymały w sumie ok. 1,5 miliona głosów, co przełożyło się na 38 mandatów (22 KPN, 16 BBWR). Zob. Obwieszczenie Państwowej Komisji Wyborczej z 23.09.1993 r. o wynikach wyborów do Sejmu Rzeczypospolitej Polskiej przeprowadzonych 19.09.1993 r. (M. P. z 1993 r. Nr 50, poz. 470).

3 Geremek, Bronistaw. Rozmowa z Adamem Michnikiem, 1993, „Gazeta Wyborcza”, 16.09.1993 r., https://wyborcza. pl/1,75248,138405.html, dostęp: 6.06.2021 r.
} 
W dalszej części wywiadu mówił też o swoim stosunku do lustracji, którą w pierwszych latach polskiej transformacji wielu traktowało jako podstawową metodę rozliczenia poprzedniego systemu politycznego. Jak wspomniał, początkowo ją popierał, ponieważ „nie można żyć z trupem w szafie”4, jednak z czasem przekonał się, że lustracji nie można przeprowadzić w sposób pozwalający na dotrzymanie zasad rządów prawa (,cywilizowany”5).

W rozmowie jednoznacznie wybrzmiewa potrzeba przyjęcia jakichś rozwiązań w odniesieniu do przeszłości okresu niedemokratycznego. Jednak rozczarowanie, jakie przebija ze słów B. Geremka - wynikające z narracyjnego zdominowania dyskursu wewnątrz jego obozu politycznego przez rewolucyjnych radykałów - spowodowało, że jasno postulował on wprowadzenie konkretnej cezury czasowej, która oddzielałaby okres komunizmu od nowo powstałej wspólnoty politycznej będącej dobrem wszystkich obywateli. Taką perspektywę na rozliczenia z przeszłością w dyskursie środkowoeuropejskim (zwłaszcza publicznym) zwykło się nazywać modelem hiszpańskim. Co się na niego, w środkowoeuropejskim pojmowaniu, miało składać? Po pierwsze, odcięcie się od przeszłości poprzez wyznaczenie jasnej cezury czasowej. Po drugie, narracyjne zorientowanie na przyszłość. Po trzecie, wiara w maksymalną inkluzywność nowo powstałej wspólnoty politycznej. Oczywiście, jest to dość duże uproszenie. Zwolennicy modelu hiszpańskiego, zwłaszcza gdy debata była toczona w ramach szeroko rozumianej publicystyki, nie brali pod uwagę ani mieszanego ustroju Królestwa Hiszpanii (państwo unitarne, składające się ze wspólnot autonomicznych), ani jego specyfiki etnicznej czy ekonomicznej ${ }^{6}$. Można pokusić się o stwierdzenie, że tzw. model hiszpański został w środkowoeuropejskiej dyskusji o przeszłości zredukowany do kilku chwytliwych społecznie haseł. Niemniej przez cały okres transformacji demokratycznej pojawiał się on (czego dobrym przykładem jest cytowny już w niniejszym artykule wywiad z B. Geremkiem) w mniejszym lub większym natężeniu jako możliwe rozwiązanie problemów z przeszłością zarówno w Polsce, jak i w innych państwach regionu. Inna ciekawa korelacja pomiędzy krajami Europy Środkowej (zwłaszcza tymi, które w 2004 i 2007 r. wstąpiły do Unii Europejskiej) a Hiszpanią pojawiła się wraz z dojściem do władzy z jednej strony socjalistów, z premierem Jose Zapatero na czele, a z drugiej - z pierwszymi sukcesami wyborczymi prawicowych (a także sceptycznych wobec narracji transformacyjnych głównego nurtu politycznego) populistów w Polsce (2005 r.) $)^{7}$, w Czechach (2006 r.) ${ }^{8}$ i na Węgrzech $(2006 \text { r. })^{9}$. W Europie Środkowej dyskusje dotyczące rozliczeń z przeszłością toczyły się już wcześniej, a sukcesy sił illiberalnych je tylko przyspieszyły. Natomiast - z dalszej

Geremek...

Geremek..

O ile dwa pierwsze elementy nie wymagają głębszych wyjaśnień, o tyle należy podkreślić, że w przypadku Hiszpanii, przede wszystkim, nie było konieczności dogłębnej przebudowy gospodarki. Istniały tam własność prywatna i wolny rynek, a w regionach zamieszkałych przez mniejszości (np. Kraj Basków) prężnie działał lokalny ruch spółdzielczy. Tego nie można absolutnie powiedzieć o Europie Środkowej. Innymi słowy, model hiszpański był w wersji oryginalnej przede wszystkim programem politycznym, a nie kompleksowym projektem reform: polityczno-gospodarczo-społecznych. „Pakt transformacyjny” zawierany był wokół gwarancji praw politycznych, których przyjęcie miało przyspieszyć procesy bogacenia się społeczeństwa, a nie jak w Europie Środkowej wyprowadzać je z biedy, w którą zostały wpędzone poprzez ideologiczne podejście do gospodarki.

7 Zwycięstwo Prawa i Sprawiedliwości z poparciem 26,99\% głosujących; odpowiednio trzecie oraz piąte miejsce Samoobrony (12,17\% głosów) i Ligi Polskich Rodzin (7,39\% głosów). W konsekwencji w pewnym momencie, po raz pierwszy w historii III RP, rząd tworzyły tylko i wyłącznie partie odrzucające fundament założycielski tej wspólnoty: porozumienie Okrągłego Stołu.

8 Zwycięstwo prawicowo-konserwatywnej (należącej do Europejskich Konserwatystów i Reformatorów) Obywatelskiej Partii Demokratycznej z poparciem 35,38\% głosujących.

9 Drugie miejsce FIDESZ-u w wyborach parlamentarnych z poparciem ponad $40 \%$ głosujących. 
perspektywy - uchwalenie w 2007 r. przez hiszpańskich socjalistów tzw. ustawy o pamięci historycznej ${ }^{10}$ było pierwszą poważną próbą zmiany zasad funkcjonowania wspólnoty, a także jej stosunku do wydarzeń z czasów dyktatury ustalonych w trakcie transformacji demokratycznej po śmierci generała Franco. Zapoczątkowało ono proces otwierania się Hiszpanii na próby prawnej regulacji społecznych pamięci zbiorowych, a także jej zbliżanie do rozwiązań stosowanych właśnie w państwach członkowskich UE wywodzących się z grona tzw. sowieckich satelitów (tj. przede wszystkim Polski, Czech, Słowacji, Węgier i Rumunii), a także częściowo byłych republik radzieckich (w tym przypadku chodzi o państwa bałtyckie: Litwę, Łotwę i Estonię). Weryfikacja tezy o zbliżeniu rozwiązań prawnych na polu pamięci, stosowanych przez hiszpańskich prawodawców zwłaszcza od 2007 r. do dziś, do tych przyjętych w państwach Europy Środkowej jest podstawowym celem niniejszego opracowania. Niemniej nie mam ambicji do przeprowadzenia dogłębnej analizy poszczególnych aktów prawnych uchwalonych przez hiszpański parlament i parlamenty wspólnot autonomicznych. W artykule chciałbym skupić się na identyfikacji fundamentalnych podobieństw i różnic w schematach działania poszczególnych prawodawców, poprzez selekcję i analizę warstwy narracyjnej poszczególnych aktów prawnych (odwołań do przeszłości w treści aktu prawnego) przy uwzględnieniu elementów społecznych i politycznych (zjawisko prawnej petryfikacji polityki pamięci), które oddziałują na procesy stanowienia kolejnych ustaw. Stąd też głównym obszarem mojego zainteresowania będą uzasadnienia uchwalenia poszczególnych ustaw pamięciowych (w systemie hiszpańskim będące immanentną częścią aktu prawnego), a nie ich część normatywna.

Pierwszym moim zadaniem jest omówienie najistotniejszych, z perspektywy środkowoeuropejskiego badacza, procesów prawnej regulacji pamięci, czyli aktów prawnych uchwalonych w Królestwie Hiszpanii, zaczynając od ustawy o amnestii z 1977 r. a na projekcie ustawy o pamięci demokratycznej kończąc ${ }^{11}$. Analiza ma służyć określeniu, na ile akty normatywne stymulowały, a na ile hamowały aktywne oddziaływanie państwa na kształtowanie się społecznej pamięci zbiorowej. W dalszej częśsi artykułu porównuję rozwiązania przyjęte przez hiszpańskich prawodawców (zarówno prawodawcę centralnego, jak i prawodawców autonomicznych) z rozwiązaniami hybrydowymi zastosowanymi w Europie Środkowej. W tym przypadku omówione zostaną zarówno rola narracji pamięci w procesach konstytucjonalizacji poszczególnych wspólnot politycznych, jak i ich wpływ na politykę instytucjonalną (model instytutów pamięci) w państwach Europy Środkowej, a także wskazane zostaną różnice i podobieństwa. Zwłaszcza ten ostatni element może mieć znaczący wpływ na poszerzenie środkowoeuropejskiej perspektywy studiów nad prawnymi politykami pamięci. Po raz pierwszy bowiem państwo spoza naszego kręgu „Zachodu porwanego"12 decyduje się na dogłębną przebudowę mitycznych podstaw powstania swojej wspólnoty politycznej. W końcu, w ostatniej części artykułu, chciałbym zastanowić się nad perspektywami dalszej ewolucji procesów prawnej regulacji społecznych pamięci zbiorowych w Królestwie Hiszpanii właśnie z perspektywy Europy Środkowej, ze szczególnym uwzględnieniem ewentualnych dalekosiężnych

10 Ustawa z 26.12.2007 r. - por la que se reconocen y amplían derechos y se establecen medidas en favor de quienes padecieron persecución o violencia durante la guerra civil y la dictadura (BOE $\mathrm{nr} 310$ z 27.12.2007 r., BOE-A-2007-22296).

11 Na dzień 6.04.2021 r. wciąż mającej status rządowego projektu ustawy. W dniu 26.05.2021 r. grupa działaczy Amnesty International wraz grupą parlamentarną ds. Pamięci i Praw Człowieka wydały oświadczenie, w którym domagają się przyspieszenia prac nad tym projektem. Zob. Amnesty International Espana, Espana: La Ley de Memoria Democratica no pude seguir esperano, 26.05 .2021 r., https:/www.es.amnesty.org/en-que-estamos/noticias/noticia/articulo/espana-la-ley-de-memoria-democratica-no-puede-seguir-esperando/, dostęp: 6.04.2021 r.

12 Zob. M. Kundera, Zachód porwany albo tragedia Europy Środkowej, „Zeszyty Literackie” 1984/5, s. 14-31. 
konsekwencji podjętych działań dla hiszpańskiego konstytucjonalizmu i przebudowy tamtejszej wspólnoty politycznej. Chciałbym w niej również wyjaśnić, dlaczego wyciąganie jednoznacznych wniosków co do zachodzących w Hiszpanii procesów wydaje mi się jeszcze przedwczesne. Europę Środkową traktuję jako swoistą bazę porównawczą, gdzie zastosowanie prawnych mechanizmów regulacji polityk pamięci stało się już rzeczą naturalną i nieszczególnie wzbudzającą społeczne kontrowersje. W tym miejscu warto zwrócić uwagę, że w naszej części kontynentu spory ogniskują się raczej wokół samej warstwy narracyjnej aktów prawnych, a nie faktu ich uchwalania.

\section{Od amnestii do ustawy o pamięci demokratycznej}

\subsection{Ustawa o amnestii (1977 r.)}

Odwołując się do teorii gier, Paloma Aguilar zauważyła, że hiszpańskie wczesne procesy transformacji ustrojowej, jak i późniejsze działania rządów demokratycznej Hiszpanii charakteryzowały się wysoką awersją do podejmowania ryzyka ${ }^{13}$. Natomiast nad doświadczeniami przeszłości, czyli okresem wojny domowej i dyktatury miała zostać spuszczona „kurtyna (...) w imię narodowego pojednania" ${ }^{14}$. Porozumienie pod hasłem: „zapomnienie za wolne wybory” było częścią paktu politycznego między opozycją a dyktaturą, który umożliwił przeprowadzenie wolnych wyborów do hiszpańskiego parlamentu w 1977 r. Wyrazem zwrotu ku przyszłości było uchwalenie w październiku tego samego roku ustawy o amnestii. Xavier Arzalluz, lider PNV (Partido Nacionalista Vasco - Baskijska Partia Nacjonalistyczna) scharakteryzował ten akt jako „,amnestię od wszystkich dla wszystkich i zapomnienie od wszystkich dla wszystkich"15. Rzeczywiście konstrukcja art. 2 ustawy o amnestii ${ }^{16}$ oddaje ducha słów wypowiedzianych przez lidera baskijskich nacjonalistów. Hiszpański ustawodawca na równi postawił w nim zarówno sprawców przestępstw politycznych, jak i ich ofiary. W punktach od a do d wymienione są wszelkie przejawy obywatelskiego nieposłuszeństwa i oporu wobec reżimu frankistowskiego, które podlegały karze. Pojawiają się tam rebelia i wszystkie inne przestępstwa penalizowane przez Kodeks sprawiedliwości wojskowej, tj. odmowa służby wojskowej z powodów światopoglądowych, odmowa ujawnienia przestępstw politycznych i wszelkie formy publicznej ekspresji uderzające we władzę. Natomiast w punktach od e do g wymienione zostały czyny dokonane przez przedstawicieli władzy i jej reprezentantów, urzędników czy też przedstawicieli resortów siłowych, którzy również podlegali amnestii. Ustawa o amnestii umożliwiała:

Rehabilitację tych, którzy odbywali wyroki więzienia za walkę przeciwko autorytarnemu reżimowi ustanowionemu po zwycięstwie wojskowych. Pozwoliła ona funkcjonariuszom publicznym odzyskać ich miejsca pracy i emerytury, jednak nie rekompensowała ono urzędnikom i wojskowym zarobków utraconych wskutek wyrzucenia ich z pracy [z powodów politycznych - dop. F.C. $]^{17}$.

13 Zob. P. Aguilar, Justice, Politics and Memory in the Spanish Transition, w: A. Brahona de Brito, C. Gonzalez-Enriquez, P. Aguilar (red.), The Politics of Memory. Transitional Justice in Democratizing Societies, Oksford-Nowy Jork 2001, s. 94-95.

14 P. Aguilar, Justice..., s. 96.

15 O.G. Encarnación, Reconciliation after Democratization: Coping with the past in Spain, „Political Science Quarterly” 2008/3V, s. 438; P. Aguilar, Justice... s. 103.

16 Ustawa z 15.10.1977 r. - de Amnestia (BOE nr 248, z 17.10.1977 r., BOE-A-1977-24937).

17 P. Aguilar, Justice..., s. 103. Wszystkie cytaty w tłumaczeniu F.C. 
Jednak jak zauważyła sama autorka rozwiązania społeczne, polityczne i prawne przyjęte w ramach tzw. paktu o zapomnieniu przez dłuższy czas nie były kontestowane w ramach dyskursu publicznego. Hiszpania, w majestacie prawa, dla pokojowego ukonstytuowania się nowej demokratycznej wspólnoty politycznej oficjalnie zrezygnowała ze swojej pamięci. Naturalnie pakt był instytucją sztuczną, wynikającą z zawartego konsensusu. W tym przypadku rezygnacja z pamięci nie oznaczała jednak wymazania pamięci zbiorowych poszczególnych społeczności, a jedynie niedopuszczenie do ich przenikania do debaty publicznej. Do połowy lat 90 . XX w. traumy okresu wojny domowej i dyktatury nie były uzewnętrzniane w przestrzeni publicznej i dyskursie głównego nurtu. Stanowić miały one zagrożenie dla wspomnianego już paktu o zapomnieniu, stanowiącego fundament hiszpańskiej, postfrankistowskiej konstytucjonalizacji.

\subsection{Tak zwana ustawa o pamięci historycznej (2007 r.)}

Wspomniana P. Aguilar za pierwszą rysę na obowiązującym porozumieniu o zapomnieniu uznała artykuł, który w 1995 r. pojawił się w gazecie El Pais. Dotyczył on działalności na terenie Kraju Basków, w latach 80. XX w., grupy GAL (Antyterrorystyczna Grupa Wyzwolenia), czyli prorządowej, paramilitarnej, jednostki odpowiedzialnej za zwalczanie ETA (Euskadi Ta Askatasuna - Baskonia i Wolność) ${ }^{18}$. Wówczas z ust jednego z wpływowych polityków PSOE (partii socjalistycznej) padło stwierdzenie, że ,jedyne prawo całkowicie odcinające [przeszłość - dop. F.C.] (full stop law), które istnieje, to to, które my demokraci uchwaliliśmy dla frankistów w październiku 1977 roku"19. Autor sugerował w domyśle, że pomimo deklarowanego pojednania, postfrankistowska prawica dalej ma ciągoty do pozaprawnych i bezprawnych działań. Z kolei Omar G. Encarnación jako jedno ze źródeł erozji paktu o zapomnieniu wskazał wydarzenie, do którego doszło w Londynie w 1998 r. Wówczas został tam aresztowany były chilijski dyktator Jose Augusto Pinochet, co z kolei miało być dowodem na to, że żaden z byłych autokratów lub ich zwolenników nie jest nietykalny:

Jednak, wypowiedzenie paktu o zapomnieniu nie może być w pełni zrozumiane bez odkrycia niezidentyfikowanych konsekwencji londyńskiego aresztowania, wydawałoby się nietykalnego Chilijczyka Augusto Pinocheta, w 1998 r. w trakcie jego szpitalnej rekonwalescencji po operacji kręgosłupa. Został on oskarżony o zbrodnie przeciwko ludzkości, a także o odegranie kluczowej roli w krwawym przewrocie wojskowym, który obalił demokratycznie wybrany rząd Salvadora Allende w 1973 r. Aresztowanie Pinocheta spadło na Chile, które wówczas było w środku prezydenckiej kampanii wyborczej, jak grom z jasnego nieba ${ }^{20}$.

Na pierwszy projekt aktu prawnego, w którym podejmowane są wątki pamięciowe Hiszpanie czekali do $2004 \mathrm{r}$. Wówczas został on wniesiony do parlamentu i ostatecznie uchwalony 26.12.2007 r. ${ }^{21} \mathrm{Z}$ uzasadnienia ustawy powszechnie nazywanej „ustawą o pamięci historycznej” wynika, że konieczność jej przyjęcia autorzy postanowili powiązać z historią hiszpańskiej transformacji. Wyjaśniając swoje motywy, już w pierwszym akapicie nawiązali do ducha pojednania, zgody i szacunku dla pluralizmu, które umożliwiły

18 Grupa GAL przez samych Basków uważana jest za „szwadron śmierci”, czyli w powszechnym rozumieniu państw hiszpańskojęzycznych jest działającą poza systemem prawa, na rzecz lub w imieniu władzy formację militarną (lub paramilitarną) rekrutowaną w celu fizycznej likwidacji jej przeciwników.

19 P. Aguilar, Justice ..., s. 104.

20 O.G. Encarnación, Reconciliation..., s. 447.

21 Zob. przypis 10. 
przyjęcie demokratycznej konstytucji w 1978 r. Dalej jej twórcy wspominają o charakterze transformacji w Hiszpanii. Stwierdzili, że przywróciła ona pełnię praw tym, którzy ponosili negatywne konsekwencje opowiedzenia się, z politycznego punktu widzenia, po złej (przegranej) stronie w czasie wojny domowej. Jak jednak podkreślili, nie wszystko zostało zrobione, a sam fakt przyjęcia demokratycznej konstytucji nie wystarczy, aby dopełnić warunków (koniecznego) narodowego pojednania. W związku z tym wszyscy ci, którzy cierpieli, muszą chociażby w symboliczny sposób powrócić do społeczeństwa. Dlatego też uznano, że taka ustawa musi zostać uchwalona w celu promowania przez organy władzy publicznej działań pozwalających zrozumieć przeszłość i zbudować demokratyczną pamięć historyczną. Poza tym, w treści uzasadnienia autorzy odwołali się do międzynarodowych deklaracji potępiających łamanie praw człowieka w Hiszpanii w okresie dyktatury (m.in. paryskiego raportu Zgromadzenia Parlamentarnego Rady Europy z 2006 r.). Podsumowując uzasadnienie uchwalenia tzw. ustawy o pamięci historycznej, jej autorzy stwierdzają wprost, że celem wniesienia projektu i przyjęcia tego aktu było zabliźnienie ran wciąż otwartych w hiszpańskim społeczeństwie oraz zadośćuczynienie obywatelom, którzy bezpośrednio lub których bliscy ponieśli konsekwencje wynikające z wojny domowej i okresu dyktatury. Ponadto stwierdzili oni, że dzięki temu możliwe będzie pogłębienie pojednania wewnątrz hiszpańskiego społeczeństwa. $\mathrm{Z}$ ostatniego zdania dowiadujemy się, że dążenie do zachowania pamięci osobistej i rodzinnej (czyli już zbiorowej) jest obowiązkiem prawodawcy, ponieważ nieznajomość przeszłości prowadzi do jej powtórzenia. $Z$ punktu widzenia niniejszego tekstu niezwykle istotne jest to, że to właśnie w tej ustawie pojawiło się kluczowe pojęcie dla zrozumienia zmian zachodzących w hiszpańskiej prawnej polityce pamięci - demokratyczna pamięć historyczna.

\subsection{Legislacja wspólnot autonomicznych}

Już sama warstwa narracyjna uzasadnienia tzw. ustawy o pamięci historycznej wskazuje na próbę odwrócenia akcentów w hiszpańskiej polityce pamięci. Od tej pory pamięć o wydarzeniach przeszłości stała się wartością gwarantowaną przez prawo, nie zaś przeszkodą w budowie hiszpańskiej demokracji i pojednania. Przyjęcie ustawy przez Kortezy Generalne otworzyło drogę do lokalnych inicjatyw służących prawnej regulacji przeszłości na poziomie wspólnot autonomicznych. Dlatego też chciałbym przyjrzeć się dwóm aktom prawnym uchwalonym przez parlamenty autonomiczne Kraju Basków ${ }^{22}$ i Walencji ${ }^{23}$. Fakt omówienia dwóch aktów „pamięciowych” przyjętych przez wspomniane wspólnoty nie oznacza, że były one jedyne. Podobne akty zostały uchwalone także m.in. w Katalonii, Nawarze i Andaluzji ${ }^{24}$. To właśnie fakt, że kolejne wspólnoty

22 Ustawa z 27.11.2014 r. - de creación del Instituto de la Memoria, la Convivencia y los Derechos Humanos (BOE nr 306 z 19.12.2014 r., BOE-A-2014-13185).

23 Ustawa z 10.11.2017 r. - de memoria democrática y para la convivencia de la Comunitat Valenciana (BOE nr 311 z 23.12.2017 r., BOE-A-2017-15371).

24 Wśród uchwalonych przez wspólnoty autonomiczne aktów prawnych, poza omawianą poniżej ustawą baskijską, znalazły się: katalońska ustawa z 31.10.2007 r. - del memorial democrático (BOE nr 284, z 27.11.2007 r., BOE-A2007-20348); katalońska ustawa z 30.06.2009 r. - sobre la localización e identificación de las personas desaparecidas durante la guerra civil y la dictadura franquista, y la dignificación de las fosas comunes (BOE nr 186 z 3.08 .2009 r., BOE-A-2009-12855); ustawa Navarry z 26.11.2013 r. - de reconocimiento y reparación moral de las ciudadanas y ciudadanos navarros asesinados y víctimas de la represión a raíz del golpe militar de 1936 (BOE $\mathrm{nr} 304 \mathrm{z} 20.12 .2013$ r., BOE-A-2013-13351); ustawa Balearów z 13.06.2016 r. - para la recuperación de personas desaparecidas durante la guerra civil y el franquismo (BOE nr 157 z 30.06.2016 r., BOE-A-2016-6312), a także andaluzyjska ustawa z 28.03.2017 r. - de memoria histórica y democrática de Andalucía (BOE nr 95 z 21.04.2017 r., BOE-A-2017-4348). 
autonomiczne zdecydowały się na wprowadzenie do swojego obiegu prawnego legislacji odnoszącej się do przeszłości i wpływającej na społeczne współpamiętanie miał być jednym z powodów, którym prawodawcy Autonomicznej Wspólnoty Walencji uzasadniali uchwalenie swojego aktu „o pamięci historycznej i wspólistnieniu Wspólnoty Walencji”.

Poza chęcią nieodstawania od innych wspólnot autonomicznych, jako powody uchwalenia swojego prawa wskazali oni dokładnie te same generalne idee, jakie zostały umieszczone w uzasadnieniu do ogólnokrajowej tzw. ustawy o pamięci historycznej. Zresztą prawodawcy z Walencji wprost stwierdzili, że oba akty pozostają w ścisłym związku przyczynowo-skutkowym. Ponadto w dalszej części (bardzo rozbudowanej) preambuły wspomnieli oni m.in., że nie istnieje możliwość pełnego pojednania, jeśli potrzeba podstawowej sprawiedliwości nie jest przez państwo zaspokajana, chociażby poprzez odszkodowania. Z kolei najlepszą drogą do budowy wspólnoty żyjącej w pokoju jest odzyskanie demokratycznej pamięci historycznej. Dodatkowo podkreślili, że uznanie praw ofiar do naprawienia krzywd musi odbywać się w ramach systemu konstytucyjnego stworzonego wraz z przyjęciem ustawy zasadniczej z $1978 \mathrm{r}$.

Natomiast Wspólnota Autonomiczna Kraju Basków uzasadniła uchwalenie własnego aktu o utworzeniu Instytutu Pamięci, Pojednania i Praw Człowieka nie tylko koniecznością upamiętnienia ofiar wojny domowej i dyktatury, ale także ofiar terroryzmu ETA i jego nielegalnego zwalczania. Co ciekawe, określenie „nielegalne zwalczanie” jest zaczerpnięte wprost $\mathrm{z}$ baskijskiej ustawy. Prawodawcy baskijskiej, autonomicznej wspólnoty politycznej intencjonalnie zestawili ze sobą działanie prorządowej, nielegalnej grupy paramilitarnej i organizacji terrorystycznej. Dzięki temu tworzą oni własną narrację pamięci, podkreślając fakt, że obie strony konfliktu sięgały po nielegalne środki, których ofiarami byli członkowie ich społeczności. Legitymizują przy tym obecną formę wspólnoty, odcinając się zarówno od własnych radykałów (ETA), jak i od rządu madryckiego (który w ramach walki z terroryzmem bardziej przywiązany był do zasady, że cel uświęca środki, niż do konstytucyjnie gwarantowanych praw człowieka i rządów prawa).

W uzasadnieniu baskijski parlament wyraźnie podkreślił także fakt, że pamięć jest prawem człowieka, a zarządzanie pamięcią demokratyczną jest częścią procesów przywracania godności ofiarom. Uzasadniając powstanie Instytutu Pamięci, Pojednania i Praw Człowieka autorzy projektu stwierdzili z kolei, że rolą pamięci nie jest umacnianie cierpienia i traumatycznych doświadczeń, ale wykorzystanie ich dla ugruntowania wartości uniwersalnych i demokratycznych.

W przypadku ustawy baskijskiej po raz kolejny więc widać powielenie pewnego zwrotu narracyjnego zapoczątkowanego ustawą o pamięci historycznej z 2007 r. Władza autonomiczna, pomimo ograniczonych uprawnień wynikających z ogólnopaństwowej konstytucji, przyjmuje w nim rolę strażnika pamięci. Ta ostatnia z kolei jest niezbędna do pełnego pojednania i dalszej, skutecznej budowy demokracji. Wyraźnie widać więc, że władze autonomii nie tylko wskazują potrzebę społecznego współpamiętania, ale także dążą, w ramach swoich uprawnien, do wypełnienia systemowej luki. Ta z kolei w domyśle wynikać ma z pasywnej polityki władz centralnych, cechującej się wspomnianą już (zidentyfikowaną przez P. Aguilar) awersją do podejmowania ryzyka na tym obszarze polityki społecznej.

\subsection{Projekt ustawy o pamięci demokratycznej (2020 r.)}

Jeżeli ustawa o amnestii wprowadzała pakt o zapomnieniu (milczeniu), ustawa o pamięci historycznej rozpoczynała proces odwrócenia akcentów narracyjnych, a ustawodawstwo wspólnot autonomicznych było powieleniem narracji zawartych w ustawie z 2007 r., 
to zaproponowaną jesienią 2020 r. przez hiszpański rząd ustawę o pamięci demokratycznej należy traktować jako przysłowiową „kropkę nad i”. Projekt tego aktu zwiastuje ostateczne zakończenie procesów toczących się w tym społeczeństwie od lat 90. ub. w. i ostateczne wypowiedzenie paktu o zapomnieniu. Naturalnie wiele zależy od kształtu, jaki ten akt prawny przyjmie po przeprowadzeniu całego procesu legislacyjnego, jednak już analiza uzasadnienia do projektu ustawy wskazuje na ostateczne zwycięstwo tendencji do budowania wspólnoty opartej na społecznym współpamiętaniu (pamięci zbiorowej), a nie na zapomnieniu. Projekt został przyjęty przez hiszpański gabinet 15.09.2020 r. ${ }^{25}$ Wicepremier i minister hiszpańskiego Urzędu rady ministrów ds. relacji z parlamentem i pamięci demokratycznej, Carmen Calvo stwierdziła wówczas, że „odkrywanie prawdy, sprawiedliwość i uczczenie ofiar, zapewnią przebaczenie i dalsze współistnienie Hiszpanów"26. Dodatkowo, podkreśliła związek między procedowanym projektem a obowiązującą od 2007 r. ustawą o pamięci historycznej. W treści samego projektu już na pierwszy rzut oka widać rozbudowę, w stosunku do poprzednich aktów, argumentacji odnoszącej się bezpośrednio do doświadczenia przeszłości. Co więcej, jego autorzy nie ograniczają się do historii własnego państwa, ale wspominają także o europejskich doświadczeniach XX w. z nazwy wymieniając Holokaust. Z treści uzasadnienia wynika także próba zmiany roli pamięci zbiorowej w hiszpańskim społeczeństwie. Autorzy projektu wprost stwierdzają, że stanowi ona czynnik kształtujący tożsamość, a rolą demokratycznej polityki pamięci jest promowanie inkluzywności społeczeństw i pluralizmu. Dlatego też organy władzy publicznej powinny ją krzewić po to, by społeczeństwo mogło dowiedzieć się i zastanowić nad tym co złego wydarzyło się w przeszłości. Samo uzasadnienie ustawy jest bardzo rozbudowane (zajmuje ponad 14 stron), stąd też szczegółowe omówienie zawartych tam narracji pamięci wymagałoby oddzielnego opracowania. Nie zmienia to jednak faktu, że poza powieleniem treści i przekazu już występujących we wcześniejszych aktach, w projekcie pojawiają się też wątki w dotychczasowej hiszpańskiej legislacji pamięciowej zupełnie nowe. Przede wszystkim w „Sekcji II” uzasadnienia autorzy ustawy sięgają już nie tylko po doświadczenia wojny domowej i dyktatury, ale także do tradycji Kortezów z Kadyksu i konstytucji z 1812 r. Dodatkowo, podkreślają oni fakt, że całe XIX i niemal całe XX stulecie zostały poświęcone walce o wyzwolenie ich społeczeństwa (naturalnie w domyśle walce oddolnej). W „Sekcji III” stwierdzają z kolei, że demokratyczna pamięć historyczna nie jest niczym nowym dla Hiszpanów, ponieważ reżim frankistowski używał totalnej polityki pamięci w celu uzasadnienia prześladowań obrońców drugiej republiki. Twierdzą oni również, że samo przyjęcie nowej ustawy jest konieczne z tego powodu, że idee i procedury zawarte w ustawie z $2007 \mathrm{r}$. stały się niewystarczające wobec zachodzących zmian i wzrostu oczekiwań społecznych ${ }^{27}$.

\section{Podobieństwa i różnice w odniesieniu do modelu środkowoeuropejskiego}

\subsection{Znaczenie społecznych pamięci zbiorowych w procesach konstytucjonalizacji}

Europa Środkowa i Wschodnia, a zwłaszcza państwa będące głównym obszarem mojego zainteresowania na potrzeby tego opracowania, charakteryzują się dużą zgodnością

\footnotetext{
25 Ministeria de la Presidencia, Relaciones con las Cortes y Memoria Democratica, Anteproyecto de Ley de Memoria Democrática, https://www.mpr.gob.es/servicios/participacion/Documents/APL\%20Memoria\%20Democr\%C3\%A1tica. pdf, dostęp: 22.02.2021 r.

26 Council of Ministers, Government approves draft bill of Democratic Memory Act, 15.09.2020 r., https://www.lamoncloa. gob.es/lang/en/gobierno/councilministers/Paginas/2020/20200915council.aspx, dostęp: 22.02.2021 r.

27 Ministeria de la Presidencia, Relaciones...
} 
co do wykorzystania narracji pamięci w procesach kształtowania wspólnot politycznych. Konstytucja, jako ostateczny produkt procesu konstytucjonalizacji, jest aktem te wspólnoty ustanawiającym. Po upadku komunizmu wszystkie państwa Europy Środkowej i Wschodniej zdecydowały się na odwołania do przeszłości - narrację pamięci - w swoich ustawach zasadniczych. $Z$ jednym wyjątkiem (Rumunia), zostały one umieszczone w preambułach, które są wyrazem ,samoobligującej woli wolnych ludzi (...) przekształconej w mityczno-moralne podwaliny wspólnoty politycznej"28. Co więcej, nawet jeśli takie narracje nie pojawiły się od razu w momencie uchwalania ustaw zasadniczych (lub przywracania jej mocy obowiązującej, jak miało to miejsce w przypadku Łotwy), to faktem jest, że generalną tendencją jest uzupełnianie środkowoeuropejskich konstytucji o takie treści. Świadczą o tym zarówno historia nowelizacji łotewskiej konstytucji ${ }^{29}$ po przegranym przez mniejszość rosyjską referendum w sprawie uznania rosyjskiego za równorzędny język urzędowy w tym państwie ${ }^{30}$, jak i sprawa nowelizacji części normatywnej konstytucji rumuńskiej ${ }^{31}$. Cel, dla którego narracje pamięci wprowadzono do orbanowskiej Ustawy Zasadniczej Węgier stanowi zupełnie odrębny materiał do analiz. Nie ulega jednak wątpliwości, że pomijając warstwę ideologiczną, węgierska ustawa zasadnicza na polu pamięci wpisuje się w regionalny trend. Jej autorzy wprost wyliczyli z jakich wydarzeń z przeszłości Węgrzy powinni być dumni, co powinni uznawać za element obcy i narzucony (m.in. komunistyczną konstytucję z 1949 r.), a także wskazali, w jakich okresach nie można mówić o Węgrzech jako państwie całkowicie suwerennym (między 19.03.1944 r. a 2.05.1990 r.) ${ }^{32}$. Poza wspomnianymi przykładami uzupełnienia środkowoeuropejskich konstytucji o narracje pamięci, pozostali twórcy liberalno-demokratycznych ustaw zasadniczych od razu sięgnęli po odwołania do przeszłości. I tak, w konstytucji ustanawiającej III RP z 1997 r. mowa jest m.in. o gorzkich doświadczeniach przeszłości, kiedy to podstawowe prawa i wolności były w naszym kraju łamane, a także o najlepszych tradycjach pierwszej i drugiej Rzeczpospolitej33. Czesi w preambule do swojej konstytucji z 1992 r. ${ }^{34}$ nawiązali do tradycji korony czeskiej i państwa czechosłowackiego. Z kolei Słowacy źródła istnienia swojego państwa odnaleźli w historii istniejącego w IX w. Państwa Wielkomorawskiego. Jiří Přibáň, omawiając preambułę polskiej konstytucji, owo połączenie odwołań do przeszłości z wartościami uniwersalnymi określił mianem ,interesującego połączenia obywatelskiego i narodowego

28 J. Přibáň, Legal Symbolism. On Law, Time and European Identity, Londyn-Nowy Jork 2007, s. 5.

29 Po tzw. referendum językowym, które odbyło się na Łotwie w 2012 r., rozpoczęto prace nad dodaniem do łotewskiej konstytucji preambuły, która ostatecznie podkreślałaby narodowy charakter państwa łotewskiego. Nowelizacja konstytucji dodająca preambułę zawierającą odwołania do narodowej przeszłości weszła w życie 19.06.2014 r.

30 Zob. I. Durviete, U. Ozolins, The Latvian referendum on Russian as a second state language, „Language Problems and Language Planning” 2016/2, s. 121-145.

31 Wskutek nowelizacji konstytucji z 2003 r. Rumunia nie jest już tylko „demokratycznym socjalnym państwem prawa, w którym godność człowieka, prawa i wolności obywatelskie, swobodny rozwój osobowości oraz sprawiedliwość i pluralizm polityczny stanowią wartości najwyższe i są gwarantowane”. Po dodaniu pomiędzy wyliczonymi wartościami uniwersalnymi, a koniecznością ich gwarancji słów „w duchu demokratycznych tradycji narodu rumuńskiego oraz ideałów Rewolucji z 1989 r.” wydaje się, że to właśnie przeszłość i tradycje wspomnianej przez prawodawców rewolucji są bazą dla „właściwego” pojmowania wartości uniwersalnych gwarantowanych przez ustawę zasadniczą w tym państwie, zob. ustawa nr 429/2003 o zmianie konstytucji Rumunii (Monitorul Oficial al României, cz. I, nr 758 z 29.10.2003 r.); A. Cosma (tłum.), Konstytucja Rumunii, http://biblioteka.sejm.gov.pl/wp-content/uploads/2016/03/ Rumunia_pol_010711.pdf, dostęp: 14.04.2021 r.

32 Ustawa Zasadnicza Węgier („Magyar Közlöny”, nr 43 z 25.04.2011 r.); J. Snopek (tłum.), Ustawa Zasadnicza Węgier, Warszawa 2012, http://libr.sejm.gov.pl/tek01/txt/konst/wegry2013.pdf, dostęp: 6.04.2021 r.

33 Konstytucja Rzeczypospolitej Polskiej z 2.04.1997 r. (Dz. U. z 1997 r. Nr 78, poz. 483 ze zm.).

34 Konstytucja Republiki Czeskiej („Sbírka Zákonů České Republiky” 1993, nr 1 z 28.12.1992 r.); M. Kruk (tłum.), Konstytucja Republiki Czeskiej, Warszawa 1994, http://libr.sejm.gov.pl/tek01/txt/konst/czechy-a.html, dostęp: 6.04.2021 r. 
patriotyzmu" ${ }^{35}$. Wydaje się, że to stwierdzenie nie powinno dotyczyć wyłącznie Polski. Wspomniana regionalna tendencja do wyposażania i uzupełniania poszczególnych konstytucji o narracje pamięci wskazuje na próby połączenia obywatelskiego i narodowego patriotyzmu wewnątrz poszczególnych wspólnot politycznych opartych na konstytucjach liberalno-demokratycznych. Narracje pamięci wyrażane w preambułach mają na celu (co najmniej) spajać społeczeństwa poprzez wyznaczenie symbolicznych ram społecznego współpamiętania w treści aktu prawnego. Niemniej mogą także podkreślać narodowy charakter tych wspólnot, jak ma to miejsce w przypadku Węgier i Łotwy. Z perspektywy moich rozważań o tendencjach prawnej polityki pamięci w Hiszpanii oraz o ich ewentualnych podobieństwach do procesów zachodzących w naszej części Europy, najważniejszym elementem zidentyfikowanym (w kontekście roli narracji pamięci wytwarzających społeczne pamięci zbiorowe) w procesach konstytucjonalizacji, a potem w samych aktach konstytucyjnych, jest kwestia tzw. samoobligującej woli wolnych ludzi.

Rozważmy następujący abstrakcyjny przykład. Dana wspólnota za swój fundament uznaje bagaż wspólnych doświadczeń, który dzieli (wspólpamięta). W momencie utworzenia wspólnoty politycznej, ostatecznie opartej na konstytucji, potrzebuje ona spoiwa. Tym „klejem” mogą być w teorii zarówno odwołania do przyszłości, jak i przeszłości. Niemniej wobec nieprzewidywalności przyszłości, przeszłość wydaje się spoiwem znacznie skuteczniejszym. Zwłaszcza, gdy poszczególne społeczności wciąż mają bagaż doświadczeń nie do końca przepracowanych. Narody Europy Środkowej w tę tendencję wpisują się niemal w stu procentach. Jak zauważyła Anna Młynarska-Sobaczewska:

W treści wstępów konstytucyjnych europejskich państw postkomunistycznych w pierwszej kolejności uwagę zwraca szerokie odwołanie do tradycji narodowej poprzez wskazanie kontekstu powstania i chlubnych doświadczeń dawniejszej państwowości - niekiedy dość odległej. Takie wypowiedzi mają oczywisty sens dla adresatów - obywateli i władzy państwowej - są instrumentem uzyskiwania przekonania o prawowitości działania twórców konstytucji i następnie władz działających na jej podstawie ${ }^{36}$.

W konsekwencji użycie odwołań do tego co znane, służące wzmocnieniu tożsamości grupowej danej wspólnoty politycznej, może być daleko bardziej skuteczne, aniżeli przedstawianie mętnej wizji świetlanej przyszłości. Ze względu na głębię doświadczeń historycznych społeczeństw środkowoeuropejskich znacznie trudniej jest budować kolektywną wiarę w przyszłość aniżeli serię analogii do przeszłości wyjaśniających teraźniejszośćc ${ }^{37}$. Nie bez znaczenia dla środkowoeuropejskiego patrzenia wstecz są również doświadczenia tzw. polityki nacjonalizmu prowadzonej na tym obszarze przez panujące tam przed I wojną światową mocarstwa: Niemcy, Rosję i Austro-Węgry. One wówczas, jak zauważył Eric Hobsbawm „nie tylko tworzyły naród, ale [wręcz - dop. F.C.] musiały go tworzyć"38. Polityka nacjonalizmu w okresie rewolucji przemysłowej i masowej migracji do miast była doskonałym narzędziem rządzących do tworzenia grupowych tożsamości, opartych na innych czynnikach niż ekonomiczne - np. kulturze, języku,

35 J. Přibáň, Legal Symbolism..., s. 85.

36 A. Młynarska-Sobaczewska, Normatywizacja tożsamości zbiorowej w preambułach do konstytucji państw postkomunistycznych, „Filozofia Publiczna i Edukacja Demokratyczna” 2013/2, s. 111.

37 Wynika to z prezentystycznego charakteru społecznej pamięci zbiorowej, tzn. reprodukujący dane wspomnienie jest bogatszy o wiedzę o jego dalekosiężnych skutkach. Innymi słowy, ocenia je wiedząc co się wydarzyło potem, a ocena jest sumą doświadczeń wspominanego wydarzenia i wydarzeń pomiędzy nim a momentem jego wspominania. Zob. B. Misztal, Theories of Social Remembering, Maidenhead-Filadelfia 2003, s. 56-61.

38 E. Hobsbawm, Wiek Imperium 1875-1914, Warszawa 2015, s. 230. 
wspólnym doświadczeniu przeszłości ${ }^{39}$. Co więcej, upadek mocarstw wraz z końcem wojny nie oznaczał odejścia nowo powstałych państw od takich schematów działania. Zarówno Polska, jak i Litwa, Łotwa, Estonia, Węgry czy Czechosłowacja (po 1938 r. Słowacja) wykazywały silne tendencje do adaptowania polityki nacjonalizmu na potrzeby budowy swoich własnych wspólnot politycznych. W konsekwencji w przypadku Europy Środkowej możemy mówić o pewnego rodzaju kontynuacji polityki odwołań do społecznego współpamiętania. Niemniej omówione powyżej uzasadnienia hiszpańskich prawodawców, zarówno centralnych, jak i autonomicznych, wskazują na uleganie podobnym tendencjom. Różnicę stanowi wciąż brak konkretnej samoobligacji na poziomie aktu konstytucyjnego. W końcu w preambule do hiszpańskiej konstytucji mowa jest jedynie o narodowej jedności, przywiązaniu do wartości liberalno-demokratycznych i de facto o wspólnym dążeniu do lepszej przyszłości ${ }^{40}$. Z kolei w aktach prawnych uchwalonych już w XXI w. pojawiają się wątki zarówno o zobowiązaniu wynikającym z doświadczenia przeszłości, jak i o konieczności zbudowania jedności, opierające się na gorzkich doświadczeniach zbiorowych. Jest to zasadnicza zmiana wobec narracji przyjętych w momencie ustanawiania tzw. modelu hiszpańskiego.

\subsection{Polityki instytucjonalne}

To właśnie element samoobligacji do podtrzymywania pamięci jest spoiwem pomiędzy Europą Środkową i Wschodnią, która zobowiązała się do tego na poziomie konstytucyjnym, a w konsekwencji stara się prowadzić politykę instytucjonalną dopełniającą to zobowiązanie, a rozwiązaniami stosowanymi (a także częściowo wprowadzanymi już w życie) w Hiszpanii. W jaki sposób owo samozobowiązanie przekłada się na politykę instytucjonalną w Europie Środkowej? Przede wszystkim, poza Łotwą i częściowo Estonią, wszystkie państwa regionu, które po upadku komunizmu zdecydowały się na dołączenie do świata zachodniego powołały do życia wyspecjalizowane instytucje zajmujące się realizacją państwowej polityki pamięci - zbiorowo nazwijmy je instytutami pamięci narodowej ${ }^{41}$. Zarówno ich ustrój, jak i zadania uregulowane są w aktach prawa państwowego - najczęściej w ustawach, które z kolei bardzo często są wyposażone w preambuły. Sam fakt zastosowania uroczystego wstępu wskazywać ma na doniosłość roli, jakie uchwalane prawo ma odegrać w danej społeczności. Narracje pamięci znajdujące się w preambułach do ustaw ustanawiających środkowoeuropejskie instytucje odpowiedzialne za umacnianie i promowanie społecznego współpamiętania, określanego mianem pamięci narodowej/narodu, są tożsame $\mathrm{z}$ tymi zawartymi w preambułach do konstytucji. W ustawach dotyczących instytutów zapisy konstytucyjne są jedynie uszczegóławiane. Przykładowo, z preambuły do ustawy ustanawiającej polski IPN możemy dowiedzieć się m.in., że polski prawodawca uchwalił ją mając na względzie ogromną liczbę ofiar i strat poniesionych w trakcie drugiej wojny światowej, i po jej

39 Zob. E.Gellner, Narody i nacjonalizm, Warszawa 2009, s. 98-111.

40 Zob. T. Mołdawa (tłum.), Konstytucja Hiszpanii, Warszawa 1993, http://libr.sejm.gov.pl/tek01/txt/konst/hiszpania.html dostęp: 4.07.2021 r.

41 Oczywiście mają one inne nazwy własne, jednak użyte określenie ma na celu podkreślenie obszaru ich działalności, a także profilu. Chodzi m.in. o polski Instytut Pamięci Narodowej, słowacki Instytut Pamięci Narodu, litewskie Centrum Ludobójstwa i Oporu, czeski Instytut Badań nad Reżimami Totalitarnymi. Instytucje o identycznym profilu istnieją także w Rumunii i na Węgrzech. W przypadku Bułgarii akcenty lustracyjne wciąż przeważają nad edukacyjnymi. Co ciekawe, nie tylko państwa, które dołączyły do świata zachodniego utworzyły takie instytucje, ale także takie, które do niego aspirują. Instytut pamięci narodowej działa obecnie również na Ukrainie. 
zakończeniu, patriotyczne zmagania narodu polskiego z systemami totalitarnymi (nazizmem i komunizmem), obowiązek ścigania zbrodni przeciwko ludzkości, a także powinność zadośćuczynienia wszystkim pokrzywdzonym przez państwo łamiące prawa człowieka $^{42}$. Z kolei z preambuły do czeskiej ustawy powołującej Instytut Badań nad Reżimami Totalitarnymi dowiadujemy się m.in., że kto nie zna swojej przeszłości skazany jest na jej powtórzenie, iż pamięć o działalności i metodach stosowanych przez państwa totalitarne jest niezbędna dla przyszłych pokoleń, a także, podobnie jak w polskiej ustawie, że ofiara poniesiona przez czeskie społeczeństwo wymaga zachowania pamięci o przeszłości ${ }^{43}$. Takie same de facto powody powołania do życia swoich narodowych instytutów pamięci podają również ustawodawca litewski44 i słowacki ${ }^{45}$. Jednak w tym ostatnim przypadku brak jest bezpośrednich analogii z treścią preambuły do konstytucji. Nie jest moją intencją szczegółowe omawianie rozwiązań prawnych regulujących działanie poszczególnych narodowych instytutów pamięci, jednak muszę w tym miejscu podkreślić, że we wszystkich przypadkach środkowoeuropejskie instytuty są zależne od władz państwowych. Są one finansowane z budżetów państw, nadzorowane przez założycieli, a ich organy są wybierane albo przez władzę ustawodawczą, albo wykonawczą.

W omawianych już wcześniej motywach uchwalenia autonomicznych ustaw pamięciowych pojawia się dokładnie ten sam schemat samoobligacji, jednak w przypadku Hiszpanii należy raczej mówić o ruchu oddolnym, a nie jak w Europie Środkowej i Wschodniej - odgórnym. Warstwa narracyjna hiszpańskiej legislacji pamięciowej została omówiona już wcześniej. Jednak na bazie rozwiązań środkowoeuropejskich warto dokonać pewnego podsumowania schematów działania prawodawców zarówno w obowiązujących ustawach ogólnopaństwowych, jak i w legislacji autonomicznej. Ustawa z 2007 r. opierała się na dwóch filarach. Po pierwsze, prawnego uznania krzywd i stworzeniu katalogu osób, którym przysługuje prawo do renty, odszkodowania lub innego świadczenia finansowego za krzywdy poniesione w związku z działalnością systemu frankistowskiego. Po drugie, na rozpoczęciu procesu instytucjonalizacji poprzez utworzenie w Salamance Centrum Dokumentacyjnego Pamięci Historycznej i Centralnych Archiwów Wojny Domowej. W ramach drugiego filaru Królestwo Hiszpanii objęło nadzorem dokumentację okresu wojny domowej, a także określiło w ustawie o pamięci historycznej tryb dostępu do zebranych dokumentów. Z punktu widzenia zwyczajnych obywateli Hiszpanii, akt ten posiadał wysoki potencjał do wprowadzenia zmiany społecznej perspektywy myślenia o roli przeszłości. Jednak, biorąc pod uwagę skalę instytucjonalizacji polityki pamięci w Europie Środkowej, a także porównując ją z dopiero raczkującą instytucjonalizacją pamięci w Hiszpanii wydaje się, że dla prowadzenia skutecznej (tj. oddziałującej masowo na społeczeństwo) prawnej polityki pamięci podjęte tam środki mogą być niewystarczające. Stąd też zapewne zdecydowano się na uporządkowanie działań na tym polu na podstawie wydanego w lutym 2020 r. królewskiego dekretu, który rozwija podstawową strukturę Kancelarii Rady

42 Ustawa z 18.12.1998 r. o Instytucie Pamięci Narodowej - Komisji Ścigania Zbrodni przeciwko Narodowi Polskiemu (tekst jedn.: Dz. U. z 2021 r. poz. 177).

43 The Act on the Institute for the Studies on Totalitarian Regimes and on the Security Service Archives (Act 181/2007 Coll.) - oficjalne tłumaczenie na język angielski.

44 Law on the Genocide and Resistance Research Centre of Lithuania (Official Gazette, 5 June 1997, No VIII - 238) - oficjalne tłumaczenie na język angielski.

45 Act on Disclosure of Documents Regarding the Activity of State Security Authorities in the Period 1939-1989 and on Founding the Nation's Memory Institute (Ústav pamäti národa) and on Amending Certain Acts (553/2002 Coll.) - oficjalne tłumaczenie na język angielski. 
Ministrów, kontaktów z sądami i pamięci demokratycznej ${ }^{46}$. Z kolei na poziomie autonomicznym funkcjonuje chociażby wspomniany w poprzednim podrozdziale baskijski Instytut Pamięci, Pojednania i Praw Człowieka. Ta instytucja swoim profilem, a także sposobem zredagowania aktu założycielskiego jest najbliższa rozwiązaniom przyjętym w Europie Środkowej. Są w nim określone zarówno zadania, jak i struktura Instytutu.

Podsumowując pokrótce kwestie polityk instytucjonalnych i wynikających z przyjętych przez instytucje władzy państwowej zobowiązań do zachowania pamięci o przeszłości, a także prowadzenia aktywnych działań na tym polu (polityk pamięci), chciałbym podkreślić, że Hiszpania jest aktualnie dopiero na etapie budowania profilu działalności instytucjonalnej, w przeciwieństwie do Europy Środkowej, gdzie takie mechanizmy zostały już wypracowane. Niemniej analiza aktów prawnych przyjmowanych w tym kraju wyraźnie wykazuje liczne podobieństwa, jeśli chodzi o rozwiązania instytucjonalne przyjmowane na Półwyspie Iberyjskim w stosunku do wypracowanych w naszej części Starego kontynentu.

\section{Dalsze perspektywy przemian prawnej polityki pamięci w Królestwie} Hiszpanii i ich ewentualne konsekwencje, czyli dlaczego jeszcze jest za wcześnie na jednoznaczne wnioski

Zanim przejdziemy do omawiania możliwych dróg dalszej ewolucji państwowej, prawnej polityki pamięci w Hiszpanii z perspektywy środkowoeuropejskiej, należy zastanowić się nad jeszcze jedną kwestią. Chodzi o określenie, ile w aktualnie prowadzonych politykach pamięci zostało z dawnych paktów i porozumień między niedemokratyczną władzą a dysydentami? Naturalnie środkowoeuropejskie przejście demokratyczne było niejednorodne pod tym względem. Pakty-porozumienia zawarto w Polsce, Czechosłowacji, Bułgarii i na Węgrzech. W Rumunii doszło do zbrojnego przewrotu, zaś w państwach bałtyckich do wybuchu społecznego, połączonego z grami politycznymi umożliwiającymi odzyskanie przez nie niepodległości.

W przypadku Hiszpanii model transformacji opartej na porozumieniu także zaistniał i jest to poza wszelką dyskusją. Co więcej, podobnie jak w przypadku porozumień zawartych w Europie Środkowej, był i wciąż jest on przedmiotem krytyki. Często przedstawiany jest jako projekt elit, które wyimaginowały sobie narodowe pojednanie w swoim własnym interesie ponad głowami ludu, który został zdemobilizowany obietnicami świetlanej przyszłości ${ }^{47}$. Zdaniem krytyków, pakty w wielu krajach doprowadziły do powstania „brudnych”" wspólnot politycznych, nieodzwierciedlających naturalnych potrzeb społeczeństw cierpiących z powodu dyktatury, a służących jedynie interesom umawiających się elit starej władzy z elitami dysydenckimi.

Rzeczywiście tego typu pakty w okresie transformacji służą bieżącym celom politycznym. Na poziomie narracyjnym w dyskursie publicznym podkreśla się zwłaszcza, że mają one znaczenie strategiczne, czyli są niezbędne dla ukonstytuowania się nowej, demokratycznej wspólnoty politycznej. Otwarte chciałbym pozostawić pytanie, czy społecznie

46 Dekret Królewski z 18.02.2020 r. - por el que se desarrolla la estructura orgánica básica del Ministerio de la Presidencia, Relaciones con las Cortes y Memoria Democrática (BOE nr 43 z 19.02.2020 r., BOE-A-2020-2386).

47 Zob. L. Desfor Edles, Rethinking Democratic Transition: A Culturalist Critique of the Spanish Case, „Theory and Society" 1995/3, s. 355-384.

48 Zob. A. Podgórecki, Kontrola spoteczna trzeciego stopnia, w: A. Kojder, E. Łojko, W. Staśkiewicz, A. Turska (red.), Elementy socjologii prawa, t. 3, Warszawa 1990, s. 78-84. 
pożądane i możliwe jest utrzymywanie paktu w perspektywie długoterminowej jako fundamentu tej wspólnoty. Niemniej zarówno w przypadku istotnej części Europy Środkowej (Polska, Węgry), jak i Hiszpanii uważam, że część „paktów transformacyjnych” została wypowiedziana, a aktywność władz na polu społecznych pamięci zbiorowych polegająca na prawnej petryfikacji społecznych osiągnięć poszczególnych polityk pamięci ma swój konkretny cel polityczny. Jak zauważyli Joanna Marszałek-Kawa, Anna Ratke-Majewska i Patryk Wawrzyński, „o ile legitymizacja zmiany może być realizowana w odwołaniu do przeszłości lub przyszłości, o tyle rekonstrukcja wizji wspólnoty musi oparta być na ukazaniu jej historycznych korzeni, tradycji i doświadczeń ją konstytuujących"49.

Biorąc pod uwagę, że procesy przebudowy (budowy) prawnej polityki pamięci w Hiszpanii wciąż się toczą (pakt został wypowiedziany, przebudowa wspólnoty ruszyła), a ich ostateczny kierunek i kształt zostanie zdeterminowany przez ostateczny kształt ustawy o pamięci demokratycznej, uważam, iż formułowanie jednoznacznych wniosków jest przedwczesne. Niemniej poniżej chciałbym omówić elementy, które mogą w przyszłości posłużyć do głębszych badań porównawczych.

Po pierwsze, zasadnicza różnica (wciąż) dotyczy obszaru, z którego pochodzi zobowiązanie do działania przedstawicieli wspólnoty politycznej (władzy) na obszarze społecznych pamięci zbiorowych i prawnej polityki pamięci. O ile w przypadku rozwiązań środkowoeuropejskich takie moralno-mityczne zobowiązanie ulokowane jest $\mathrm{w}$ treści konstytucji (a więc dochodzi do pionowej transmisji narracji pamięci: od władzy do społeczeństwa), o tyle w przypadku Hiszpanii, po analizie uzasadnień do przyjmowanych ustaw pamięciowych, odnoszę wrażenie, że wciąż jest to rodzaj imaginacji przedstawicieli władz (najczęściej autonomicznych) o konkretnym profilu ideowym (antyfrankistowskim). O ile na poziomie argumentacyjnym hiszpańscy prawodawcy uzasadniają przyjęcie poszczególnych ustaw potrzebą społeczną, czyli dążą do uruchomienia transmisji pionowej, o tyle w rzeczywistości jest to raczej dopiero próba wprowadzenia tych kwestii do głównego nurtu polityki (działanie oddolne, ewentualnie próba wprowadzenia tematyki do dyskursu). Po drugie, inne jest zaplecze ideowe grup interesu sięgających po politykę pamięci. W konsekwencji z profilu ideologicznego wynika też konkretna treść narracji lokowanych w poszczególnych aktach prawnych. Europa Środkowa odwołuje się do takich pojęć jak naród, wspólnota, czy też doświadczenie historyczne narodu. Co więcej, wraz z rozwojem systemów illiberanych, przede wszystkim w Polsce i na Węgrzech (a także w ramach budowy państwa narodowego na Ukrainie), wszystkie instytucje państwowe w ramach tej imaginacji powinny być narodowe. W Hiszpanii używane są natomiast odwołania do praw człowieka, godności czy praw podmiotowych. Społeczna pamięć zbiorowa chroniona, wspierana i budowana przez instytucje państwowe ma być demokratyczna, nie zaś narodowa. Niemniej warto pamiętać, że oba te przymiotniki są tylko wskazaniem na nurt ideowy, z jakim utożsamiają się twórcy legislacji „pamięciowej”. Owo niedookreślenie widoczne jest w doświadczeniach środkowoeuropejskich, gdzie składowe pamięci narodowej determinuje bieżąca polityka, a nie ustawodawca w momencie uchwalenia aktu prawnego ${ }^{50}$.

49 J. Marszałek-Kawa, A. Ratke-Majewska, P. Wawrzyński, Polityka pamięci i kształtowanie tożsamości politycznej w czasie tranzycji postautorytarnej. Analiza porównawcza, t. 2, Warszawa 2016, s. 111.

50 Innymi słowy, to czy pamięć zbiorowa promowana przez dany obóz polityczny jest demokratyczna czy też narodowa nie ma większego znaczenia dla identyfikacji mechanizmów jej prawnej regulacji. Jest to tylko i wyłącznie wskazanie na nurt ideowy, który jest bliższy dążącym do prawnej regulacji ram społecznego współpamiętania. Wcześniej w Europie Środkowej, a obecnie w Hiszpanii, działania prawne były i są pokłosiem decyzji politycznej. 
W treść ustaw hiszpańskich wpisane są również elementy sprawiedliwości okresu przejścia demokratycznego. Jednak w obu omawianych przypadkach nie ma, i nie było w trakcie transformacji mowy o pełnym, systemowym zastosowaniu mechanizmów sprawiedliwości tranzycyjnej ${ }^{51}$. Treść narracji pamięci determinowana jest doświadczeniem poprzedniego systemu. Wspomnieli o tym zresztą autorzy projektu ustawy o pamięci demokratycznej stwierdzając wprost, że to nie polityka pamięci jako taka jest nowością dla hiszpańskiego społeczeństwa, ale jej demokratyczna treść. Wydaje się, że oficjalnym celem utrwalenia demokratycznej pamięci historycznej na gruncie tamtejszych aktów prawnych jest chęć podkreślenia przynależności demokratycznej Hiszpanii do świata zachodniego. Z czego to może wynikać? Izraelski filozof Avishai Margalit identyfikuje upokorzenie jako:

jedno z najbardziej dominujących - bolesnych, traumatycznych, obciążających - doświadczeń indywidualnych i zbiorowych. W centrum namysłu stawia szczególny rodzaj upokorzenia, upokorzenie instytucjonalne, czyli takie, które wynika z działania instytucji, w odróżnieniu od upokorzenia, które mogą zadawać sobie jednostki, nie działając z ramienia instytucji ${ }^{52}$.

Margalitowskie przyzwoite społeczeństwo ma przede wszystkim nikogo nie upokarzać. Systemy niedemokratyczne z kolei łatwo odnajdują się w profilu upokorzenia instytucjonalnego, ponieważ w ich DNA wpisane jest „wykluczanie osób lub grup ze społeczeństwa, obywatelstwo drugiej kategorii, ekonomiczny wyzysk (nie)członków społeczeństwa [czy też - dop. F.C.], kulturowe upokorzenie przez dehumanizujące reprezentacje" 53 . Zarówno w przypadku hiszpańskiego wyobrażenia o demokratycznej pamięci historycznej, jak i przeważającego w Europie Środkowej o pamięci narodowej widać, że prawna regulacja pamięci zbiorowej (na poziomie deklaratywnym) ma na celu przede wszystkim ucieczkę od zagrożeń powtórzenia się wydarzeń z przeszłości. W przypadku Hiszpanii ciągłemu podkreślaniu (niedookreślonej i nie zdefiniowanej) demokratyczności pamięci przyświeca konkretny cel, jakim jest (na poziomie deklaratywnym) utrwalenie wartości uniwersalnych świata zachodniego. Przeszłość i pamięć dyktatury mają służyć jako przykład antydemokratycznego, nieprzyzwoitego społeczeństwa. Jednak, co wynika z procesów, jakie już w Europie Środkowej nastąpiły, w praktyce celem jest przebudowa wspólnoty politycznej w kierunku pożądanym przez konkretną formację polityczną.

Z kolei fakt transferu narracji pamięci do treści aktów prawnych jest cechą wspólną prawnej polityki pamięci prowadzonej w Hiszpanii i w Europie Środkowej. Zatem, czy mamy do czynienia z upodobnieniem się Królestwa Hiszpanii do Europy Środkowej poprzez zapożyczenie przez nią od państw postkomunistycznych mechanizmów prawnej regulacji pamięci zbiorowych? Na poziomie przyjętych konkretnych rozwiązań legislacyjnych widoczne są liczne korelacje. Podobnie, jeśli chodzi o argumentację, która ma przemawiać za ich zastosowaniem. W obu przypadkach władza zatroskana o los obywateli bierze na siebie ciężar ochrony ich pamięci. Co więcej, czyni to z podobnych pobudek, czyli z chęci budowy przyzwoitego społeczeństwa opartego na pamięci o krzywdach wyrządzonych w przeszłości. Zupełnie przeciwstawna jest za to treść

\footnotetext{
Zob. R. Teitel, Transitional Justice, Nowy Jork 2000, s. 213-228.

K. Liszka, Avishai Margalit - stownik pojęć podstawowych, „Prace Kulturoznawcze” 2020/1, s. 18.

K. Liszka, Avishai Margalit..., s. 19.
} 
samych narracji. Europa Środkowa wciąż brnie w wizje wspólnoty narodowejo ${ }^{54}$ z kolei Hiszpanie odwołują się do wartości ogólnoludzkich.

Jak już wspominałem, głębsze porównania będą możliwe, gdy projektowana ustawa o pamięci demokratycznej przybierze ostateczny kształt. Niemniej warto w tym miejscu zastanowić się nad możliwościami, jakie rysują się przed Hiszpanią z perspektywy środkowoeuropejskiego obserwatora.

Po pierwsze, jedną z opcji jest głębsza instytucjonalizacja na wzór narodowych instytutów pamięci (które w tym przypadku będą zapewne „demokratyczne”). Gdy więc w 1991 r. Kenneth Maxwell zastanawiał się, czy hiszpański model przejścia demokratycznego jest odpowiedni dla obszaru postkomunistycznego ${ }^{55}$, prawdopodobnie nie spodziewał się, że to Hiszpanie sięgną ${ }^{56}$ po rozwiązania instytucjonalne wypracowane w Europie Środkowej.

Po drugie, w mojej opinii, jeśli hiszpańscy socjaliści chcieliby doprowadzić do dokończenia procesów rozpoczętych w tym państwie ustawą o pamięci historycznej z 2007 r., to $-\mathrm{z}$ punktu widzenia społecznej praktyki polityki pamięci - nie będą w stanie tego zrobić bez nowelizacji konstytucji (np. na wzór łotewski lub rumuński). Oczywiście zdaję sobie sprawę, że zarówno z praktycznego, jak i z formalnego punktu widzenia taki krok nie jest konieczny. Jednak wielkość nowego ładunku symbolicznego, jaki przy użyciu narzędzi prawnych jest tam wprowadzany wymagać będzie ostatecznie zmian na poziomie aktu ustanawiającego wspólnotę polityczną. Obecne władze w Hiszpanii dążą do przebudowy wspólnoty i oparcia jej na micie republikańskim. W takim przypadku klamrą domykającą procesy zmiany oficjalnych narracji musi być wprowadzenie narracji pamięci do treści konstytucji. Tylko petryfikacja na poziomie aktu prawnego, którego późniejsza zmiana będzie najtrudniejsza z politycznego (i formalnego) punktu widzenia, może zapewnić trwałość odwróconych państwowych narracji pamięci, a w konsekwencji - możliwość zaszczepienia w społeczeństwie nowych idei ${ }^{57}$.

Wiele będzie zależało od społecznej odpowiedzi na państwową politykę promowania demokratycznej pamięci historycznej. Na pierwszy rzut oka wydaje się, że posiada ona znacznie większy potencjał symboliczny aniżeli znane, ale także już zgrane odwołania do wspólnoty narodowej znane z Europy Środkowej. Niemniej kluczowe znaczenie będą miały tu narzędzia zastosowane przez elity w celu zaszczepienia tej idei w społeczeństwie. Jak zauważył Paul Connerton, „próba zerwania w sposób ostateczny ze starym porządkiem napotyka na rodzaj historycznego dziedzictwa i staje wobec groźby rozbicia się o nie" 58 . Dużą rolę w procesach społecznego współpamiętania odgrywa też upływ czasu. O ile w przypadku Europy Środkowej siły polityczne kontestujące pakty transformacyjne sięgnęły po polityki pamięci stosunkowo szybko, o tyle w Hiszpanii pakt o zapomnieniu funkcjonował przez niemal 30 lat. Długofalową konsekwencją takich działań może być z kolei umocnienie w głównym nurcie politycznym dyskusji o sensie utrzymania monarchii. Jeśli mit republikański stanie się częścią hiszpańskiej tożsamości

${ }_{54}$ Zob. F. Cyuńczyk, Konstytucyjne ramy pamięci? Narracje pamięci w preambułach do konstytucji państw postkomunistycznych, w: A. Czarnota, M. Paździora, M. Stambulski (red.), Nowy Konstytucjonalizm. Polityczność, tożsamość, sfera publiczna, Warszawa 2021, s. 207-232.

55 Zob. K. Maxwell, Spain's Transition to Democracy: A Model for Eastern Europe?, „Proceedings of the Academy of Political Science" 1991/1, s. 35-49.

56 Fakt, na ile są świadomi takich zapożyczeń, również powinien być ciekawym wątkiem do analiz, nie tylko prawnych.

57 Zob. E. Hobsbawm, Mass-Producing Tradition: Europe 1870-1914, w: E. Hobsbawm, T. Ranger (red.), The Invention of the Tradition, Cambridge 2014, s. 263-208; B. Misztal, Theories of Social Remembering, Filadelfia 2003.

58 P. Connerton, Jak spoteczeństwa pamiętaja, Warszawa 2012, s. 49. 
konstytucyjnej, wówczas dążenie do powstania III Republiki wydaje się być jego naturalną konsekwencją. Wynika to z tego, że na gruncie polityki społecznej fakt istnienia monarchii może zostać wtedy ostatecznie sprzężony z paktem politycznym, który przestał obowiązywać (umożliwiającym transformację i sztuczne zapomnienie), a także z powstałą w oparciu na nim wspólnotą polityczną, która również przestała istnieć.

$\mathrm{Z}$ punktu widzenia badań nad pamięcią zbiorową, procesy, które będzie stymulować ewentualne przyjęcie ustawy o pamięci demokratycznej, będą bardzo interesującym obszarem badawczym $\mathrm{i}$ to nie tylko dla socjologów prawa.

\title{
Back to the Past? Evolution of the Legal Mechanisms Regulating Collective Memories in Spain from the Central European Perspective
}

\begin{abstract}
The primary objective of the paper is to conduct case studies of Spanish historical memory policies introduced after 2007 and their comparison to actions undertaken in the same field in the CEE countries. The primary research hypothesis is that case studies of different memory policies of post-communist countries can help in examining the model of dealing with the reformulation of the past in the Kingdom of Spain. This paper reflects on similarities and differences between the Spanish and the Central and Eastern European models of dealing with the past, with due regard for the applied legal tools. Hence, I have presented some of the specific elements of the post-communist constitutionalization in the CEE, including memory narrations being incorporated in the constitutions of the region. In addition, I intend to demonstrate the impact of memory narrations on individual states' institutional policies in the CEE and in the Kingdom of Spain. As a final point, I endeavor to reveal the hidden potential of memory laws as contributors to the Spanish political community reconstruction.
\end{abstract}

Keywords: memory laws, memory juridification, collective memory, constitutionalism, democratic transition 


\section{BIBLIOGRAFIA / REFERENCES:}

Aguilar, P. (2001). Justice, Politics and Memory in the Spanish Transition. In A. Brahona de Brito, C. Gonzalez-Enriquez, P. Aguilar (eds.), The Politics of Memory. Transitional Justice in Democratizing Societies. OxfordNew York: Oxford University Press.

Connerton, P. (2012). Jak spoteczeństwa pamiętają. Warszawa: Wydawnictwo Uniwersytetu Warszawskiego.

Cyuńczyk, F. (2021). Konstytucyjne ramy pamięci? Narracje pamięci w preambułach do konstytucji państw postkomunistycznych. In A. Czarnota, M. Paździora, M. Stambulski (eds.), Nowy Konstytucjonalizm. Polityczność, tożsamość, sfera publiczna. Warszawa: Scholar.

Desfor Edles, L. (1995). Rethinking Democratic Transition: A Culturalist Critique of the Spanish Case. In Theory and Society 24, 355-384.

Durviete, I., Ozolins, U. (2016). The Latvian referendum on Russian as a second state language. In Language Problems and Language Planning 40, 121145 .

Encarnación, O. G. (2008). Reconciliation after Democratization: Coping with the past in Spain. In Political Science Quarterly 123, 435-460.

Gellner, E. (2009). Narody i nacjonalizm (2 wydanie). Warszawa: DIFIN.

Hobsbawm, E. (2014). Mass-Producing Tradition: Europe 1870-1914. In E. Hobsbawm, T. Ranger (eds.), The Invention of the Tradition. Cambridge: Cambridge University Press.

Hobsbawm, E. (2015). Wiek Imperium 1875-1914. Warszawa: Krytyka Polityczna.

Liszka, K. (2020). Avishai Margalit - słownik pojęć podstawowych. Prace Kulturoznawcze 24, 13-31.

Marszałek-Kawa, A., Ratke-Majewska, A., Wawrzyński, P. (2016). Polityka pamięci $i$ ksztaltowanie tożsamości politycznej $w$ czasie tranzycji 
postautorytarnej. Analiza porównawcza. Warszawa: DIFIN.

Maxwell, K. (1991). Spain's Transition to Democracy: A Model for Eastern Europe? In Proceedings of the Academy of Political Science 38, 35-49.

Misztal, B. (2003). Theories of Social Remembering. Maidenhead: Open University Press.

Młynarska-Sobaczewska, A. (2013). Normatywizacja tożsamości zbiorowej w preambułach do konstytucji państw postkomunistycznych. Filozofia Publiczna i Edukacja Demokratyczna 2, 104-133.

Podgórecki, A. (1990). Kontrola społeczna trzeciego stopnia. In A. Kojder et al. (eds.), Elementy socjologii prawa, t. 3. Warszawa: Wydawnictwo Uniwersytetu Warszawskiego.

Přibáň, J. (2007). Legal Symbolism. On Law, Time and European Identity. London-New York: Ashgate.

Teitel, R. (2000). Transitional Justice. New York: Oxford University Press. 